DOI: $10.33741 / 0435-1991.41 .16$

\title{
FIRST-TIME BLOOD DONORS PATTERN-BASED ON THE RESULTS OF LABORATORY, MORPHOLOGIC, BIOPHYSICAL, AND BIOCHEMICAL PERIPHERAL BLOOD TESTS
}

\author{
Muliarchuk O. V., Vydyborets S. V. \\ Shupyk National Healthcare University of Ukraine, Kyiv, Ukraine
}

\begin{abstract}
Introduction. In spite of the lately increasing number of scientific research programs on donor blood storage, integrated solution of this problem remains a challenging open issue.

Aim. To investigate the laboratory, morphological, biochemical, and biophysical characteristics of erythrocytes of first-time donors in order to further use the obtained indicators as controls in the comparative analysis.
\end{abstract}

Materials and methods. The study included 160 first-time donors (83 men and 77 women) donating for the first time. The following methods were used: general blood tests, blood chemistry, radioimmune and enzyme-immunoassay, statistic methods.

Results. Results of the performed laboratory, morphologic, biochemical, and biophysical tests: erythrocyte index determination, reticulocyte count, red blood cell distribution width, optical transmission of erythrocytes, test for aggregation and penetrability of erythrocyte membranes, effectiveness of erythropoiesis value determination in first-time donors erythrocytes demonstrated that the examined person making the group of donors are practically healthy people whose test results are within normal limits for their age group.

Conclusions. The blood parameters of donors obtained as a result of complex clinical and laboratory studies can be used for comparative analysis in similar studies as a control, for early detection of possible changes in erythrocytes in regular donors depending on the donor experience.

Keywords: blood donors, erythrocytes, morphological parameters, blood donation.

Competing interests: the authors declare no conflict of interests in relation to this article.

Financing resources: research had no industry funding. 


\title{
ХАРАКТЕРИСТИКА ПЕРВИННИХ ДОНОРІВ \\ ЗА РЕЗУЛЬТАТАМИ КОМПЛЕКСНИХ КЛІНІКО-ЛАБОРАТОРНИХ, МОРФОЛОГІЧНИХ І БІОХІМІЧНИХ ДОСЛІДЖЕНЬ ПЕРИФЕРИЧНОЇ КРОВІ
}

\author{
Мулярчук О. В., Видиборець С. В. \\ Національний університет охорони здоров'я Украӥни імені П. Л. Шупика, \\ Киів, Україна
}

\section{Резюме}

Bступ. Методологічним підгрунтям даного дослідження є системний підхід, який дозволив вперше різнобічно $і$ комплексно дослідити лабораторні морфологічні, біохімічні і біофізичні характеристики еритрочитів донорської крові.

Мета. Дослідити лабораторні, морфологічні, біохімічні і біофізичні характеристики еритрочитів донорської крові первинних донорів крові для подальшого використання отриманих показників як контрольних при порівняльному аналізі.

Матеріали і методи. Обстежено 160 донорів (83 чоловіків и 77 жінок), які здійснювали донацію вперше в житті. В роботі застосовували наступні методи досліджень: загальноклінічні лабораторні, біохімічні, радіоімуного $і$ імуноферментного аналізу, статистичні.

Результати. Результати проведених нами клініко-лабораторних, морфологічних, біохімічних $і$ біофізичних досліджень: визначення індексів еритрочитів, підрахунок кількості ретикулочитів, визначення показників агрегації і проникливості еритроцитарних мембран, показника ефективності еритропоезу у первинних донорів свідчили про те, щуо донори, які включені в основну групу, є практично здоровими, отримані результати відповідають нормальним фізіологічним значенням.

Висновки. Отримані нами за результатами комплексних клініко-лабораторних досліджень параметри крові донорів можна використовувати для порівняльного аналізу при проведенні аналогічних досліджень як контрольні, для раннього виявлення можливих змін в еритроцитах у активних донорів залежно від донорського стажу.

Ключові слова: донори крові, еритроцити, морфологічні параметри, донація крові.

\section{Introduction}

Blood transfusion service and its social component - donorship must be the priority areas of the state policy because the results of its work are of paramount importance $[1,2]$. The main task of the blood transfusion service is a supply of high-quality components for blood transfusion therapy. Quality of blood components is a compliance of properties and specifications of the blood component supplied to the recipient with the set standards. The strict order of conformance with the approved regulations and procedures is important at all technological states and is a cornerstone of blood transfusion service products 
quality. All actions, planned and implemented, starting with planning donorship and ending with the finished product manufacturing and storage conditions, are important for ensuring the quality as the final result $[3,4]$.

In spite of the lately increasing number of scientific research programs on donor blood storage, integrated solution of this problem remains a challenging open issue [3-5]. Despite the important role of serotonin in the pathogenesis of numerous pathological processes and diseases, its changes in the content in first-time blood donors have been ignored by researchers, which, in turn, prompted us to the scientific research.

Aim. To investigate the laboratory, morphological, biochemical, and biophysical characteristics of erythrocytes of first-time donors in order to further use the obtained indicators as controls in the comparative analysis.

\section{Materials and methods}

The study included 160 first-time registered donors ( 83 men and 77 women) who donated in clinical centers of the Chair of Hematology and Transfusion Medicine of Shupyk National Healthcare University of Ukraine. According to the age classification (WHO, 1991), first-time donors (F-TD) were divided into three subgroups: young donors - 48 (26 men and 22 women) aged 20-34, middle-aged donors - 62 (30 men and 32 women) aged 35-44, ripe age donors ( 27 men and 23 women) aged 45-59. All donors were examined pursuant to the Medical Examination Procedure for Donors of Blood and (or) its Components approved by Decree of the Health Ministry of Ukraine no. 385 dated 01.08.2005 - «On Infectious Safety o Donor Blood and its Components» as donors whose blood is used for production of components.

Before donation, blood donors filled questionnaire and were examined by qualified specialists pursuant to the requirements of the applicable Medical Examination Procedure for Donors of Blood and (or) its Components. Hemoglobin was measured for all the donors (RR: $\mathrm{M}$ - no less than $130 \mathrm{~g} / \mathrm{l}, \mathrm{F}$ - no less than $120 \mathrm{~g} / \mathrm{l})$. Blood donation volume was determined on the basis of hemoglobin test (max volume $-450 \mathrm{ml}$ excluding blood volume drawn for the test (up to $40 \mathrm{ml}$ ).

After blood donation, alanine aminotransferase (ALT, RR 0.1$0.68 \mathrm{mmol} / \mathrm{h}-1)$ level was measured in donors' blood; it was also tested for hemotransmissive infections (HIV $1 / 2$, hepatitis B, hepatitis $\mathrm{C}$, syphilis).

The mean age of the F-TD was $38.90 \pm 1.31$ ( $20-59$ years old). The mean age of the male donors was $39.66 \pm 1.53$ (22-59 years old). The mean age of female donors was $37.56 \pm 2.45$ ( $20-57$ years old).

All 160 F-TD were practically healthy and eligible for donation subsequent to the result of the survey, examination by specialists, and hemoglobin level. 
Markers of transfusion transmissive infections were all negative. ALT level was within the normal limits. The research was approved by the Ethics Committee of Shupik National Healthcare University of Ukraine.

Hemoglobin measuring, erythrocyte, leukocyte, platelet count, and calculation of RBC indices were performed in the laboratory of the Kyiv Municipal Blood Center of executive body of the Kyiv City Council (Kyiv CitybState Administration) on the automated analyzer PCE-210 (ERMA, Japan). Determination of serum iron was performed according to batophenantroline method. Total iron binding capacity (TIBC) was evaluated by transferrin (TF) saturation with three-valence iron. Unsaturated (latent) iron binding capacity (UIBC) was calculated as difference between TIBC and iron concentration. TF saturation coefficient (TSC) was calculated as serum iron (SI)/TIBC ratio. Serum TF was determined by TIBC value. Serum ferritin (FN) was evaluated by radioimmunoassay technique using «IRMO-Ferritin» set (Belarus). Blood viscosity parameters, aggregation of erythrocytes and platelets were determined in accordance with S.I. Moiseev et al. method - panel of methods allowing for evaluation of the main parameters that are determinative for blood viscosity properties - aggregation of platelets and erythrocytes, erythrocyte deformability, hematocrit [6]. Optical transmission of erythrocytes (OTE) was determined in accordance with D. Danop, I. Marikovaski method [7]. Physical and chemical parameters of erythrocyte membrane penetrability (PEMP) was evaluated in accordance with O.I. Kulapina et al. method [8]. Red blood cell distribution width (RDW) was determined automatically on automated hematology analyzer PCE-210 (ERMA, Japan). Effectiveness of erythropoiesis value (EEV) was evaluated in accordance with G. I. Kozinets et al. method [9].

All data obtained in the course of the research were statistically processed. The research scope sample was analyzed by Student's t-test and Mann-Whitney nonparametric U-test, correlation and dispersion analyses. For data analysis, IBM SPSS Statistics 22.0 and Excel XP were used.

\section{Results}

In F-TD, mean hemoglobin level was $(138.88 \pm 0.95) \mathrm{g} / \mathrm{l}$ : in men $-(142.72$ $\pm 0.81) \mathrm{g} / \mathrm{l}(135 \mathrm{~g} / \mathrm{l}-150 \mathrm{~g} / \mathrm{l})$, in women - $(132.06 \pm 0.89) \mathrm{g} / \mathrm{l}(127 \mathrm{~g} / \mathrm{l}-140 \mathrm{~g} / \mathrm{l})$. Hemoglobin level was higher in male than in female donors $(\mathrm{p}<0.001)$. In F$\mathrm{TD}$, erythrocyte count was, on an average, $(4.63 \pm 0.03) \times 10^{12} / 1$. In the examined male donors it was, on an average, $(4.76 \pm 0.03) \times 10^{12} / 1\left(4.5 \times 10^{12} / 1\right.$ $\left.-5.0 \times 10^{12} / 1\right)$, in female $-(4.40 \pm 0.03) \times 10^{12} / 1\left(4.2 \times 10^{12} / 1-4.7 \times 10^{12} / 1\right)$. Erythrocyte count was higher in men than in women $(\mathrm{p}<0.001)$. In the examined male donors, leukocyte count was in the mean $(6.86 \pm 0.21) \times 10^{9} / 1$ 
$\left(4.4 \times 10^{9} / 1-8.6 \times 10^{9} / 1\right)$, in female $-(6.79 \pm 0.29) \times 10^{9} / 1\left(8 \times 10^{9} / 1-9,2 \times\right.$ $\left.10^{9} / 1\right)$. Average leukocyte count in the group of first-time donors was $(6.83 \pm$ $0.17) \times 10^{9} / 1$. In F-TD, platelet count was, on an average, $(203.40 \pm 1.97) \times$ $10^{9} / 1$. In the examined male donors it was, on an average, $(204.38 \pm 2.69) \times$ $10^{9} / 1\left(180 \times 10^{9} / 1-230 \times 10^{9} / 1\right)$, in female $-(201.76 \pm 2.71) \times 10^{9} / 1(190 \times$ $\left.10^{9} / 1-210 \times 10^{12} / 1\right)$. Erythrocyte count was higher in men than in women $(\mathrm{p}<0.001)$. In the group of F-TD, reticulocyte count was, on an average, $(0.88 \pm 0.05) \%$. In the examined male donors, mean reticulocyte count was $(0.87 \pm 0.05)$, in female $-(0.88 \pm 0.04) \%$. There were no significant age- or sex-dependent differences between mean leukocyte, platelet and reticulocyte counts in the examined first-time donors $(\mathrm{p}>0.05)$.

Mean cell hemoglobin $(\mathrm{MCH})$ was, on an average, $(30.63 \pm 0.25) \mathrm{pg}(27-$ $33 \mathrm{pg})$. In female donors, mean $\mathrm{MCH}$ was $(29.40 \pm 0.42) \mathrm{pg}(27-31 \mathrm{pg})$, in male $-(31.13 \pm 0.24) \mathrm{pg}(28-33 \mathrm{pg})$. There was no significant sex-dependent difference in $\mathrm{MCH}$ in the examined F-TD ( $\mathrm{p}>0.05)$. Mean corpuscular volume $(\mathrm{MCV})$ was, on an average, $(93.41 \pm 0.91)(84-97 \mathrm{fl})$. In female donors, mean MCV was $(94.22 \pm 1.69) \mathrm{fl}(89-97 \mathrm{fl})$, in male $-(92.29 \pm 1.01) \mathrm{fl}(84-96 \mathrm{fl})$. There was no significant sex-dependent difference in MCV in the F-TD $(\mathrm{p}>0.05)$.

In all F-TD, mean corpuscular hemoglobin concentration (MCHC) was, on an average, $(34.38 \pm 0.23) \%(33-35 \%)$. In female donors, mean MCHC was $(34.35 \pm 0.31) \%(33-35 \%)$, in male $-(34.41 \pm 0.41) \%(33-35 \%)$. There was no significant age- or sex-dependent difference in MCHC in this group $(\mathrm{p}>0.05)$.

We performed cytometry of peripheral blood erythrocytes of the F-TD. Mean corpuscular diameter was, on an average, $(7.19 \pm 0.06) \mathrm{mcm}^{3}$, micro- and schistocytes $-(4.80 \pm 0.14) \mathrm{fl}$, anisocytosis $-(4.02 \pm 0.14) \%$, discocytes $(80.41 \pm 0.45) \%$, abnormal shape $-(19.59 \pm 0.55) \%$. There was no significant age- and sex-related difference between average mean corpuscular diameter, micro- and schistocyte count, $\%$ of anisocytosis, discocytes and abnormally shaped erythrocytes in F-TD $(\mathrm{p}>0.05)$.

In F-TD, mean serum iron (SI) was $(20.04 \pm 2.03) \mu \mathrm{mol} / \mathrm{l}$, and it was higher in male donors $(\mathrm{p}<0.01)$, TIBS was, on an average, $(57.25 \pm 2.49) \mu \mathrm{mol} / \mathrm{l}$. In the examined male donors, TIBS was, on an average, $(56.52 \pm 2.37) \mu \mathrm{mol} / \mathrm{l}$ $(52.05-61.03 \mu \mathrm{mol} / \mathrm{l})$, in female $-(58.55 \pm 2.20) \mu \mathrm{mol} / \mathrm{l}(54.87-62.05 \mu \mathrm{mol} / \mathrm{l})$. TIBS was higher in females $(\mathrm{p}<0.01)$.

In the examined male donors, UIBS was, on an average, (35.77 \pm 4.07) $\mu \mathrm{mol} / \mathrm{l}(28.05-43.37 \mu \mathrm{mol} / 1)$, in female - $(39.78 \pm 3.53) \mu \mathrm{mol} / \mathrm{l}(34.18-$ $45.65 \mu \mathrm{mol} / \mathrm{l})$. In general, the mean UIBC for the group of the F-TD was $(37.21 \pm 4.31) \mu \mathrm{mol} / 1$. UIBC was higher in females $(\mathrm{p}<0.01)$. 
TSC was, on an average, $(35.18 \pm 4.90) \%$. In the examined male donors, man TSC was $(36.88 \pm 4.74) \%(28.60-46.10 \%)$, in female $-(32.17 \pm$ $3.63) \%(26.40-38.30 \%)$. TSC was higher in male donors $(\mathrm{p}<0.01)$.

Serum TF was, on an average, $(2.23 \pm 0.10) \mathrm{g} / \mathrm{l}$. In the examined male donors, serum TF was $(2.20 \pm 0.09) \mathrm{g} / \mathrm{l}(2.03-2.38 \mathrm{~g} / \mathrm{l})$, in female $-(2.28 \pm$ $0.09) \mathrm{g} / 1(2.14-2.42 \mathrm{~g} / \mathrm{l})$. Serum TF was higher in female donors $(\mathrm{p}<0.01)$. In the examined male donors, serum FN was, on an average, $(24.91 \pm 2.14) \mathrm{mcg} / \mathrm{l}$ $(20.64-30.12 \mathrm{mcg} / \mathrm{l})$ in female $-(19.19 \pm 1.41) \mathrm{mcg} / \mathrm{l}(17.15-21.82 \mathrm{mcg} / \mathrm{l})$. In general, the mean serum FN in the group of F-TD was $(22.85 \pm 3.36) \mathrm{mcg} / \mathrm{l}$. Serum FN was higher in male donors $(\mathrm{p}<0.001)$. In young donors, serum iron was, on an average, $(21.43 \pm 1.56) \mu \mathrm{mol} / \mathrm{l}(19.1-24.0 \mu \mathrm{mol} / \mathrm{l})$, in middle-aged donors $-(20.17 \pm 1.86) \mu \mathrm{mol} / \mathrm{l}(17.4-24.6 \mu \mathrm{mol} / \mathrm{l})$, in ripe age donors $(18.03 \pm 1.14) \mu \mathrm{mol} / 1(16.4-19.8 \mu \mathrm{mol} / \mathrm{l})$. Serum iron level in young F-TD was higher than in middle-aged $(p<0.05)$ and ripe age $(p<0.001)$ donors. The level of serum iron in middle-aged donors was higher than in the ripe age donors $(\mathrm{p}<0.01)$. Average level of serum TF in young donors was $(2.13 \pm$ $0.06) \mathrm{g} / \mathrm{l}(2.03-2.24 \mathrm{~g} / \mathrm{l})$ in middle-aged $-(24 \pm 0.05) \mathrm{g} / \mathrm{l}(2.15-2.35 \mathrm{~g} / \mathrm{l})$, in ripe age $-(2.35 \pm 0.05) \mathrm{g} / 1(2.26-2.42 \mathrm{~g} / \mathrm{l})$. Average level of serum FN in young donors was $(24.01 \pm 4.17) \mathrm{mcg} / \mathrm{ml}(17.21-30.12 \mathrm{mcg} / \mathrm{ml})$, in middleaged donors $-(22.88 \pm 3.08) \mathrm{mcg} / \mathrm{ml}(17.49-26.55 \mathrm{mcg} / \mathrm{ml})$, in ripe age donors $-(21.34 \pm 2.18) \mathrm{mcg} / \mathrm{ml}(17.15-24.21 \mathrm{mcg} / \mathrm{ml})$. Serum FN in young donors was higher than in the ripe age $(\mathrm{p}<0.05)$. There was no significant difference in serum FN level between F-TD young and middle-aged donors and middle-aged and ripe age donors.

In all F-TD, RDW was $(79.81 \pm 0.81) \mathrm{fl}(79.01-80.71 \mathrm{fl})$. There was no significant sex-related difference in RDW in the examined F-TD $(\mathrm{p}>0.05)$. The margin of errors for mean values for erythrocyte populations varied between $0.4-4.1 \%$ of the reference value. In most cases, it did not exceed 1$2 \%$. According to the criteria approved for biology and medicine, accuracy achieved in the process of research is quite high. The data obtained is reliable and can be used both in practical work and as reference points. In F-TD, OTE was $(0.006 \pm 0.001) \mathrm{g} / \mathrm{ml}(0.005 \pm 0.001-0.007 \pm 0.001 \mathrm{~g} / \mathrm{ml})$. There was no significant sex-related difference in OTE in the examined F-TD $(\mathrm{p}>0.05)$. There was no significant sex-related difference in erythrocyte aggregation, platelet aggregation index and hematocrit in F-TD ( $p>0.05)$.

We established that in the group of F-TD solid concentration in erythrocytes $(\%)$ was $(43.74 \pm 0.11) \mathrm{g}$ per $100 \mathrm{ml}$, solid content in erythrocyte was $(27.54 \pm$ $0.17) \mathrm{pg}$, water content in erythrocyte $-(67.09 \pm 0.18) \%$, PEMP $-(1.49 \pm$ $0.01) \mathrm{U}$. There was no significant sex-related difference in solid concentration 
in erythrocyte, solid content in erythrocyte, water content in erythrocyte and PEMP in F-TD $(\mathrm{p}>0.05)$.

We established that in the group of F-TD erythrocyte fragmentation was, on an average, $(1.74 \pm 0.09) \%(0.75-3 \%)$. There was no significant sex-related difference in erythrocyte fragmentation in F-TD $(\mathrm{p}>0.05)$.

We established that in the group of F-TD EEV was $(0.070 \pm 0.001) \cdot 10^{12} / 1$ : in female donors it was, on an average, $(0.069 \pm 0.002) \times 10^{12} / 1$, in male donors $(0.071 \pm 0.002) \times 10^{12} / 1$. First of all, EEV of $(0.070 \pm 0.001) \times 10^{12} / 1$ in F-TD demonstrates that this is the number of erythrocytes formed and is released daily into one liter of peripheral blood in this category of donors (hence in healthy people).

\section{Discussion}

Results of the performed laboratory, morphologic, biochemical and biophysical tests: erythrocyte index determination, reticulocyte count, RDW, OTE, test for aggregation and penetrability of erythrocyte membranes, effectiveness of erythropoiesis value determination in F-TD erythrocytes demonstrated that the examined person making the control group of donors are practically healthy people whose test results are within normal limits for their age group.

In order to preserve health of donors and ensure quality of blood components received at the time of donation, thorough checkup of donors, including, apart from the main and biochemical peripheral venous blood parameters, morphologic, biophysical and rheological parameters of erythrocytes is highly recommended before donation.

It is recommended to add OTE to the list of screening tests for eligibility confirmation for F-TD. In combination with affordability, time rate and simplicity, information value of this test will allow for its wide application in blood transfusion service institutions as a part of the eligibility screening.

\section{Conclusions}

The blood parameters of donors obtained as a result of complex clinical and laboratory studies can be used for comparative analysis in similar studies as a control, for early detection of possible changes in erythrocytes in regular donors depending on the donor experience.

\section{Література}

1. Карпенко ФН, Богдан ЕЛ, Мигаль ТФ, Барц ВА, Митраков ЮЮ. Донорство крови и ее компонентов в Республике Беларусь. Гематология. Трансфузио-

\section{References}

1. Karpenko FN, Bogdan EL, Migal' T.F, Barz VA, Mitrakov YY. Donorstvo krovi i ee komponentov v Respublike Belarus' [Donation of blood and ist 
логия. Восточная Европа. 2017. 3;4; 619-28.

2. Magnussen K, Ladelund S. Handling low hemoglobin and iron deficiency in a blood donor population: 2 years' experience. Transfusion, 2015: 55;10: 2473-8.

3. Masse B. Donor research in Australia: Challendes and promise. Transfus. Med. Hemother., 2014: 41; 4: 296-301.

4. Ngoma AM. Blood donor deferral among students in Northern Japan: Challenges Acead. Transfus. Med. Hemother., 2017. 41;4: 251-6.

5. Yin Y-H, Li C-Q, Liu Z. Blood donation in China: substaining efforts and challenges in achiving safety and availability. Transfusion, 2015: 55; 10: 2523-30.

6. Моисеев СИ, Осипов ВК, Ефимов КВ. Быстрый способ оценки реологических свойств крови. Гематология и трансфузиология. 1990. 35; 10: 36-37.

7. Danop D, Marikovasky Y. Determination of density distribution of red cell population. J. Lab. Clin. Med. 1964. 64: 668-73.

8. Кулапина ОИ, Киричук ВФ, Зайцева ИА. Показатель проницаемости мембран эритроцитов при тонзиллярной патологии. Клин. лаб. диагностика. 2006. 6: 53-5.

9. Козинец ГИ, Хакимова ЯХ, Быкова ИА. Цитологические особенности эритрона при анемиях. Ташкент: Медицина, 1988: 15-6.

Стаття надійшла 16.08.2021

Контакти: muliarchukov@gmail.com components in the Republic of Belarus]. Hematology. Transfusiology. Estern Europe, 2017. 3;4; 619-28. (in Russian).

2. Magnussen K, Ladelund S. Handling low hemoglobin and iron deficiency in a blood donor population: 2 years' experience. Transfusion, 2015: 55;10: 2473-8.

3. Masse B. Donor research in Australia: Challendes and promise. Transfus. Med. Hemother., 2014: 41; 4: 296-301.

4. Ngoma AM. Blood donor deferral among students in Northern Japan: Challenges Acead. Transfus. Med. Hemother., 2017. 41;4: 251-6.

5. Yin Y-H, Li C-Q, Liu Z. Blood donation in China: substaining efforts and challenges in achiving safety and availability. Transfusion, 2015: 55; 10: 2523-30.

6. Moisejev SI, Osipov VK, Efimov KV. Bystryi sposob otsenki reologicheskih svojstv krovi. Gematologija i transfusiologija. 1990. 35; 10: 36-37. (in Russian).

7. Danop D, Marikovasky Y. Determination of density distribution of red cell population. J. Lab. Clin. Med. 1964. 64: 668-73.

8. Kulapina OI, Kirichuk VF, Zaitseva IA. Pokazatel pronitsaemosti erytrocytov pri tonzillarnoj patologii. Klin. Lab. Diagnostika. 2006. 6: 53-5. (in Russian).

9. Kozinets GI, Chakimova YCh, Bykova IA. Zitologicheskije osobennosti erytrona pry anemijah. Tashkent: Meditsina, 1988: 15-6. (in Russian). 